\title{
Institutional Aspects of Provision of Sustainability of Budget System of the Russian Federation
}

\author{
N. G. Vovchenko ${ }^{1}$, O. B. Ivanova ${ }^{1}$, E. D. Kostoglodova ${ }^{1} \&$ T. F. Romanova ${ }^{1}$ \\ ${ }^{1}$ Rostov State University of Economics, Rostov-on-Don, Russian Federation \\ Correspondence: N. G. Vovchenko, Rostov State University of Economics, 69, Bolshaya Sadovaya str., \\ Rostov-on-Don, 344002, Russian Federation. Tel: 7-863-263-3080. E-mail: main@rsue.ru
}

Received: June 30, 2015 Accepted: July 7, 2015 Online Published: July 15, 2015

doi:10.5539/ass.v11n20p235 URL: http://dx.doi.org/10.5539/ass.v11n20p235

\begin{abstract}
The article views institutional aspects of provision of budget system of the Russian Federation in the context of development of financial institutions for strengthening of income base of budget system, reduction of non-oil and gas deficit, targeted use of budget assets, increase of debt sustainability of budget, increase of effectiveness and transparency of budget system, and creation of stable financial conditions of development of the Russian Federation.
\end{abstract}

Keywords: financial institutions, fiscal transparency, budget sustainability

\section{Introduction}

Financial institutions have a systematizing role in fiscal system, as they create foundations for socio-economic development of the state. At that, their formation should be oriented at the best foreign practices from the point of view of implementation of institutions (including expenses for receiving necessary information concerning institution, its distribution, signing corresponding contracts, and passing the laws), which will facilitate the achievement of socially significant results and sustainability of budget system.

Large importance and significance of institutions in economic reality is widely known. Definitions "institutions", "institutional environment", "institutional changes", "institutional structure", "institutional order" vary a lot. Therefore, it is important to determine their hierarchical interconnection.

According to theoretical basis of institutional theory, institutions are treated as rules and standards of behavior, i.e., they should be viewed as regulatory principles, allowing or forbidding some or other actions. On the one hand, such rules limit or stimulate actions of economic subjects, and, on the other hand, - allow them to make rational choice and forecast the actions of those that surround them (Kuzminov, 2005). Therefore, financial institution is a complex cooperation of formal and informal principles, rules, and norms which determine and regulate activities of person in the sphere of finances.

The main elements of the system of financial institutions are structural characteristics of financial system and the whole socio-economic development of the state. At that, it is possible to distinguish three foundations of institutional elements - regulatory, normative, and cognitive (Scott, 1995).

\section{Theoretical Base and Materials}

On the basis of the theory of institutional changes of D. North, institutional environment, or institutions, can be presented by group of individuals which are involved into targeted activities. Limitations which are bound by institutional structure (together with other limitations) determine variety of possibilities. D. North considered that the main restraining factor in economic development were transaction expenses which emerge due to the fact that information has a value and is asymmetrically distributed among the parties of the exchange. So, institutional structure decides which types of knowledge are necessary for receiving maximal feedback, and competition urges organizations to constantly invest in receipt of knowledge and experience for the purpose of development and survival (Leontyev, 2011).

In its turn, institutional structure of budget system reflects ordered totality of financial institutions, in which basis the formal and informal rules are in dynamics of development, appearing and supplementing each other in interconnection. The recurring interconnections of economic agents allow forecasting evolutionary tendencies in 
development of financial institutions. In this context, it is necessary to determine the order of usage of institutes, i.e., institutional order of budget system. In these approaches, the landmark is definition by M. Olson (Olson, 1998), who thought that institutional order is a systemic component of economic order which determines fundamental regularities while performing economic activities by main agents, independently of spheres and types of activities.

It is possible to suppose that institutional order is similar to the notion of institutional environment, under which one understands a complex of formal and informal institutes and their mechanisms of state regulation, including budget tools which ensure the sustainability of fiscal system.

Behavioral postulates of reformers and lawmakers of institutions and their users often do not coincide. This is due to the difference in views as to the order of society. The reason of this is that very often institutions borrow and copy, without understanding of their functioning in new institutional environment (Dryzek, 1996). Differences between logical understanding of formal and informal approaches lead to institutional traps. This may be referred to fiscal institutions, when their non-efficiency is determined by the gap between financial practices and formal rules. In order for designed financial institution to be effective, it should be functionally necessary and correspond to real economic development.

A huge role in development of financial institutions in particular country belongs to adaptation of the best practices and new theories in the sphere of state finances under conditions of globalization era. Publication of the book "New state finances" changed the understanding of modern development of state finances from the point of view of change of proportion between market and state regulators, understanding of the role of intergovernmental organizations and whether some of their traditional functions could be performed more rationally and effectively by members of global markets or private-public partnerships. All of this proves the thesis that state finances constantly develop. Change of the balance between market and state transformed the methods of management of state finances - both at national level and at the level of intergovernmental organizations. Essentially, international cooperation transforms from intergovernmental process into "multi-actor" process. Under the conditions of new financial technologies, openness leads to interdependence which could be faced only through cooperation (Inge Caul, 2006).

The International Monetary Fund, the World Bank, and the Organization for Economic Cooperation, and other international organizations reconsider the standards and examples of the best practices for evaluation of fiscal transparency, which leads to emergence of many new initiatives and fiscal transparency becomes a mainstream.

In 2014, the International Monetary Fund reconsidered the "Code of transparency in the tax sphere" which determined the set of clear principles, evaluated with the matrix of practices. That is, each indicator within this matrix shall be evaluated from the point of view of compliance of existing practices of budget reports with "basic", "suitable", or "leading practice". In other words, there is a certain set of tools, the use of which is recommended by international organizations for provision of fiscal transparency, but still there is no common standard. That's why these tools have to adapt to the interests of specific users within particular country.

Traditionally, the quality of the system of management of state finances is evaluated through indicators of common economic and fiscal stability, effectiveness of distribution of expenses, and operational efficiency. Thus, the IMF defines fiscal transparency as "fullness, clarity, authenticity, promptness, and actuality of state financial reports and public openness of the process of decision making in the sphere of financial policy". In 2012, the UN passed the "High-level principles on transparency". In this context, fiscal transparency facilitates the increase of efficiency of state expenses, improves access to external financing, and reduces fiscal risks. Main tools that allow increasing the transparency include publication of budget reports and compliance with international standards (Morgner, 2015).

The goal of fiscal transparency is the increase of efficiency of economic policy by means of deleting uncertainties in the sector of state finances and the increase of external control. Empirical research proves that fiscal transparency not only improves the indicators in the sphere of state finances but reduces the cost of state loans, reduces the actuality of the problem of corruption, increases the probability of the fact that effective, just, stable, and sustainable fiscal policy will help to achieve positive economic, social, and ecological effect. Together with fiscal transparency, in order to provide the possibility of comparing different countries, the index of budget openness is determined - which is a direct average of quantitative evaluations of 95 items of survey that refer to the problem of budget openness, normalized according to the scale of $0-100$. The index of budget openness of Russia from 2006 to 2012 increase from 47 points out of 100 to 74 points, and Russia left the $28^{\text {th }}$ position out of 59 countries to the $10^{\text {th }}$ position out of 100 countries (Richard Hughes, 2014). 


\section{Results}

In the sphere of provision of budget sustainability in the Russian Federation, a very important role belongs to strengthening of institutional order of budget system of formation of its sustainable institutional environment, namely: strengthening of budget foundations (including adaptation of budget rules, non-budget mechanisms of excessive financing, modern evaluation of budget risks, increase of fiscal transparency; reforming state expenses (based on strengthening of tax and budget discipline and increase of effectiveness of management of state expenses, determination and specification of current expenses); pension reform (based on effective management of long-term budget expenses, balance of pension sources, and transparency of pension plans); strengthening of foundations of monetary policy and evaluation of stability of financial sector.

The measures for perfection of incomes of federal budget should be the measures for allocation of reserves of current taxation system: increase of efficiency of state control in regulation of production and turnover of alcoholic products; increase of income from foreign trade operation; increase of tax control for VAT refund; perfection of incomes from realization of mineral resources; optimization of taxes on incomes from realization of measures related to diversification of country's economy; rationalization of system of subsidies; optimization of controlling activity of tax and customs bodies; increase of incomes from federal property. These measures should be aimed at provision of long-term balance and sustainability of budget system and support of necessary financial reserves.

In the sphere of expenses of federal budget, the top-priority directions are the following: social policy, national security, and issues of development of national economy. For the purpose of reduction of risks of execution of expenditures of federal budget, it is necessary to perfect the work as to increasing the quality of management of state finances and effectiveness of use of budget assets. There is a necessity for systemic approach to formation of the complex of state programs aimed at full-scale implementation of program-oriented principle of budget execution. This direction requires formation of single approaches to collection and provision of information on execution of program indicators, perfection of statistic observations of the results of expenditures programs, as multivariance of methods in calculation and methods of receipt of data complicates high-quality control for implementation of state programs. Interrelations of federal budget and budges of state non-budget funds should be aimed at reduction of inter-budget transfers.

This context includes interrelations of the federal budget with the Pension Fund of the Russian Federation which are complicated by the following problems: aberrant incomes of the Pension Fund of Russia due to reduced tariffs, expenses for valorization, expenses for "non-insurance" periods, compensations for accrued but unpaid taxes, and transfer for balance. These problems should be solves with the help of stage-by-stage reforms which conform to the principles of the balance of the pension system: increase of the pension insurance record (up to 15 years), necessary for acquiring right for old age pension; implementing indicator which characterizes minimal volume of insurance taxes necessary for acquiring right for old age pension; fixation of the tariff of insurance taxes into the Pension Fund of Russia for insurance and funded pension; increase of critical value of wages, from which insurance fee is paid; indexation of fixed fee for insurance share of pensions according to the inflation level; termination of pension rights during the period of pension receipt; preservation of values of pension and guarantees for minimal level of pensions for non-employed pensioners (not lower than living wages in the region).

The direction of regulation of the level of deficit of the federal budget should include measures aimed at expansion of sources of internal loans, from privatization, and by means of change of surplus balances on the accounts of the Reserve Fund. As to the Reserve Fund, it is necessary to increase the efficiency of assets management. As to the National Welfare Fund, it is important to implements measures related to financial tools which are aimed for development of infrastructural projects, providing maximal effect of economic growth with minimal risks of assets allocation. A very actual issue is one of the increase of effectiveness of managing assets of the Fund through the increase of its profitability with minimization of interest and currency risks, which is aimed at preservation of sustainability of the budget system. The issues of perfection of management of national debt should be handled simultaneously with the initiatives of modernization of infrastructure of national financial market, reduction of the cost of public borrowings, and preservation of Russia's presence in the international market of capitals.

Also, the primary measures include the "large-scale" budget consolidation, which requires regulation of non-oil deficit and increase of the Reserve Fund and the National Welfare Fund up to the planned levels. Orientation at new rules should destroy connection between tax \& budget policy and fluctuations of oil prices - this condition is the most important in preservation of sustainability of budget system. 
This budget rule determines substantial limits for federal expenditures, which will significantly decrease their volatility, setting upper limits for federal expenditures at the level of non-oil and gas incomes, calculated according to the estimated oil price.

The new rule is an important institution determining budget sustainability, as it determines the gap between budget and fluctuations of oil prices and supposes the mechanism of reserves. At present, this direction requires certain corrections. This is due to the fact that oil reserves are formed in ineffective way - therefore, there is a necessity for correspondence between upper limits of expenses and budget parameters for three-year plan; it is impossible to redirect yearly streams of oil reserves; non-oil payment credits should reflect on reserve funds. All the above measures should become a real basis for budget planning within the budget process. Reserve funds may be used as financial resources for investments, which should be a strategic vector of development and significant factor of economic dynamics of Russia. It is advisable to conduct reserve funding for Russia, as well as to correct expenditure policy for the sale of preservation of reserve assets.

Budget reform should have a multi-vector nature of development for the purpose of preservation of financial and economic stability. Thus, in order to preserve the reserves and optimization of expenditure policy, it is necessary to conduct structural reforms. Structural budget reforms should implement: parametric pension reform; increase of efficiency of budget expenditures with perfection of evaluation of investment expenses and inspection procedures; constant privatization of government enterprises, especially enterprises with low level of profitability.

In order to solve these issues, it is necessary to prevent the risk components of economic dynamics, which supposes the development of working algorithm of evaluation of risks of economic dynamics of financial transformations, taking into account the risk of oil prices reduction, risk of real outflow of capital, and risk of critical situation in the bank sphere.

The matrix of risk evaluation shows events which can lead to significant change of dynamics of indicators of basic scenario. Besides macro-economic volatility, the state is subject to wide range of budget risks caused by sources which are not easily to take into account in macro-economic analysis. These "discrete" budget risks include:

1) non-macro-economic factors which can lead to deviation of incomes from the forecast to certain side (an example of this is uncertainty as to the use of tax subsidies by population and enterprises);

2) risks related to assets and obligations, including the ones which are not shown on the balance as of now. These risks include re-financing risks and the influence of changes of interest rates, currency exchange rates, and other variables in the value of assets and liabilities belonging to the government (in Russia, balances of large government-controlled companies create significant additional layer of risks in this sphere);

3 ) contingent obligations, when the state could bear the costs in future, but their value and time are not specified;

4) long-term or unlimited risks which are difficult to be evaluated quantitatively (in Russia, they include expenses for pension provision and healthcare of aging population) (Richard Hughes, 2014).

Analytical evaluation of fiscal transformations proves the necessity for accounting of consolidated changes in fiscal system and directly influences the budget sustainability. Implementation of the set goals requires the landmarks for the formation of program budget aimed at long-term strategy, which, in its turn, increases the quality of formation and execution of the budget.

At all stages of budget process, the initial aspect is the increase of openness and financial transparency of the state sector. Implementation of this direction could be performed within the development of integrated system "electronic budget" with simultaneous unification of document control for budget and accounting information. In addition to the issues of provision of transparency, it is necessary to mention the development of the unified portal of the budget system of the Russian Federation, which should be the main informational resource about state and municipal institutions. Integrity of information requires development and confirmation of federal standards of accounting, including particular standards of state sector. An innovational institution in the sphere of provision of transparency of fiscal activity should be the formation of "budget map" for citizens, which will increase the publicity of information for the purpose of management of state finances and provision of budget openness.

Conduct of the procedures of transparency requires the improvement of the forms and methods of financial control. Financial control and audit should acquire new order for the purposes of elimination of problems and drawbacks in the usage of budget assets and prevention of possible violations, which, it its turn, requires 
monitoring and analysis of qualitative indicators of control activity. Monitoring should cover the execution of state tasks and publication of its results on the informational web-site, which, one the one hand, will increase the transparency of budget activities, and, on the other hand, will facilitate the optimization of the use of budget expenditures. These measures will be the basis of formation of efficient informational state system of payments which is a source of incomes of the budget system of the Russian Federation.

In the issues of optimization of the use of state assets and implementation of program obligations, a huge role belongs to the development of institution of public-private partnership, which significantly influences the sustainability of the budget system.

Public-private partnership, while optimizing the combination of budget and non-budget sources on a long-term basis, determines the efficiency of all state projects. Perfection of this institution should feature the additional legal frameworks and new mechanisms of execution of obligations which should include insurance of risks and claims for contracts (concessions) and claims from object's users. Therefore, it is necessary to develop the practice of use of targeted capital (in the sphere of education, science, and culture).

Socio-economic environment of Russia should include the conditions for attracting direct investments and their effective use, so it is necessary to reconsider effective guarantees, financial supports, and tax subsidies for development of public-private partnership.

One of the top-priority institutions in the increase of sustainability is the institution of tax regulation, the work of which should correspond to modern economic development and top-priority directions of economic policy.

Very actual issues are development and effective use of tax on real estate property instead of current tax on land and personal property tax. An important role belongs to differentiated approach to tax on mineral resources extraction depending on the conditions of oil and gas extraction, using the coefficients with reduced value for new and worked-out gas deposits. Activization and protection of financial market under the conditions of development of financial integration and long-term stimulation of investment climate requires the formation of new rules of taxation of operations with securities.

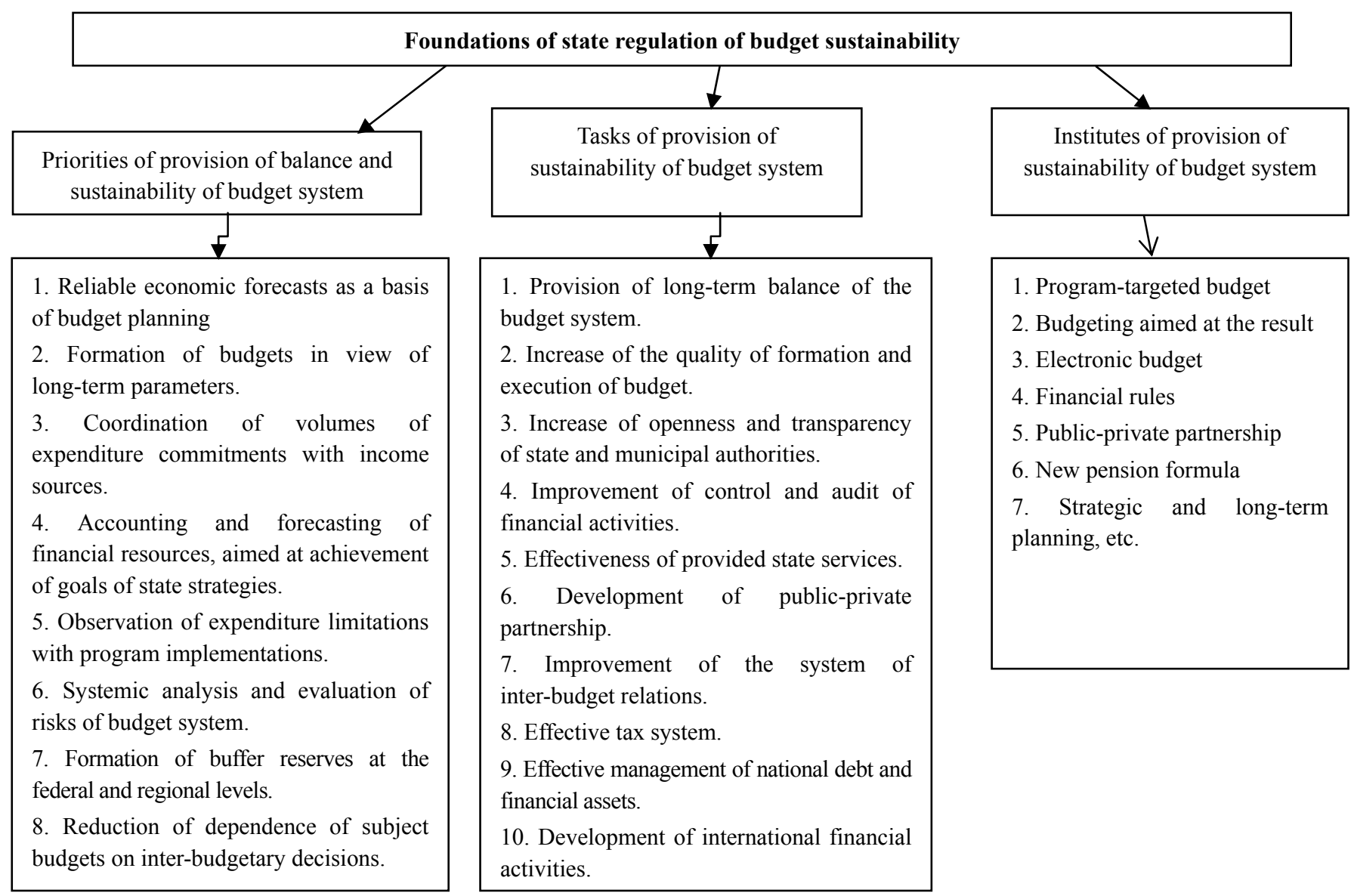

Figure 1. Conceptual directions of state regulation of sustainability of budget system 
Full reflection of redistribution of economic resources through the budget requires opening the level of incomes reduction due to tax expenditures. Despite the efforts for evaluation of the value of tax expenses, authorities do not have an official methodology for tax expenses calculation. It is very difficult to directly calculate tax expenditures. Evaluation of losses of budget incomes requires the control tax - defined as a structure of tax rates, withholdings, and accounting regime which would have been created in absence of any tax expenditures. Analysis of tax expenses also requires selecting one of the three methodologies of evaluations: on the basis of lost income, growth of income, or expenses equivalent. The Russian government hasn't yet accepted any official approach.

Issues of preservation of sustainability of budget system and financial system on the whole are related to managing national debt and financial assets. The capital market should become an efficient financial environment for financing the budget deficit and should support the efficient liquidity, ensure the wide range of investors, which will become an important condition for financing of top-priority projects of development of infrastructural spheres of economy and increase the efficiency of managing the assets of the budget system.

An important issue in the preservation of budget sustainability is formation of efficient mechanism of allocation and preservation of free money from the budgets of all levels.

Optimization of all financial operations, regulation, and control require creation of single regulator of financial markets in the basis of the national Bank of Russia. This measure will increase the efficiency of controlling activities through consolidated control. This measure is important for the development of the processes of Russia's integration into the global financial space and for effective investments of budget reserves and pension reserves into investment projects which have national importance. Regulation of financial market will facilitate the perfection of infrastructure of securities market and financial market on the whole, but in this context formation of accounting standards with the use of International financial reporting standards and accounting, which could be conducted under the supervision of the Council for standards of accounting with orientation at international standards of audit.

Issues of competitiveness of Russia and increase of the fiscal system are related to the development of financial relations at the level of cooperation with international financial organizations and in the direction of creation of such important structure as Council for fiscal stability. Activities of the Council for fiscal stability will be aimed at reduction of systemic financial risks and formation of measures for support for fiscal sustainability, according to the best foreign practices developed by the global financial society.

These measures for development of institutes of budget sustainability should be an efficient landmark for the Budget Code of the RF, which should be included into the state programs for perfection of key stages of the budget process. Effective, transparent, and responsible management of budget process through new institutes is a basic condition for modernization of economy, increase of living standards, and achievement of strategic goals of socio-economic development of Russia.

On the basis of the conducted analysis of institutional order of the budget system, it is possible to determine conceptual foundations of state regulation of budget sustainability in the Russian Federation (Fig 3.2).

The methods of the analysis of the budget system have multi-variant characteristics and are reasoned from the point of view of debt sustainability and from the point of view of risks assessment (Vlasov S., 2013), which has a decisive direction for diagnostics of sustainability and confirms the parameters of "functional finances" (David, 2004) for short-term, mid-term, and long-term perspective.

Evaluation of sustainability of budget system, based on the methodology of the IMF, consists in the usage of aggregated index of fiscal stress which is calculated on the basis of signal indicators in the sphere of state finances. These indicators include the level of national debt, interest rate for national debt, budget balance, etc.

In the selected approaches, the sustainability of budget system should be viewed at the level of budget of extended government and take into account the totality of the budgets of all levels and their totality.

Evaluation of sustainability of budget system of any national system requires the selection of signal indicators. These are indicators connected to the dependence of federal budget from external situation: debt sustainability, volume of export, volume of import, etc.

Therefore, from the authors' point of view, conceptual foundations of state regulation of budget sustainability should be accompanied by modern methods of analysis of sustainability of budget system, including stage-by-stage algorithm of its diagnostics. In this situation, it is advisable to judge from specific conditions of functioning of budget system - in other words, from the current institutional order of budget system. 
One of the main indicators of reduction of dependence of federal budget from external situation is reduction of non-oil and gas deficit. If, for example, during 2-3 years prior to the year, prior to the year, for which the federal budget is created, non-oil and gas deficit increases, it is a signal for verification of sustainability of the federal budget.

The following methodological approaches for evaluation of the analysis of sustainability of the budget system of the Russian Federation, based in the step-by-step algorithm, could be recommended.

1. Development of methodology of calculation of aggregated indicators of sustainability of the federal budget on the basis of macro-economic indicators, such as: Urals oil prices, USD/barrel; gas prices (contract average, including the CIS countries), USD/thousand $\mathrm{m}^{3}$; investments, billion RUB; volume of import (for the range of goods, accounted by the Federal Customs Service of Russia), billion USD; volume of export (for the range of goods, accounted by the Federal Customs Service of Russia), billion USD; profit of profitable organizations, RUB billion; wage fund, RUB billion; GDP, billion RUB.

$I^{\text {st }}$ step. Creating trend models for the offered macro-economic indicators.

$2^{\text {nd }}$ step. Finding - on the basis of created trend models - forecasting values of stated macro-economic indicators for the planned period.

$3^{r d}$ step. For each year of the planned period, the calculation of the relative indicators reflecting the share of the first seven offered macro-economic indicators as to GDP of the corresponding year.

$4^{\text {th }}$ step. Calculation of aggregated indicator of the structure of the federal budget for each year of the planned period.

$5^{\text {th }}$ step. Analysis of aggregated indicators of the federal budget structure of the planned period: if these indicators do not differ much or are almost similar, this shows the fairly sustainable federal budget for the planned period; if these indicators are rather different, it is necessary to perform additional analysis of the federal budget structure.

2. Analysis of the federal budget structure on the basis of aggregated index of fiscal stress.

Aggregated index of fiscal stress is calculated in the basis of analysis of signals of the variety of complementary indicators which characterize the structure of the federal budget for the year prior for the planned one (Vlasov S., 2013).

Complementary indicators create three clusters:

$1^{\text {st }}$ cluster - main budget indicators: national debt ( $\%$ of GDP); structural initial primary balance ( $\%$ of potential GDP); interest rate for national debt, adjusted to the rate of GDP growth (predicted average value for 5 years);

$2^{\text {nd }}$ cluster - long-term budget trends: growth of federal spending for pensions (predicted value in 30 years, $\%$ of GDP); growth of federal spending for healthcare (predicted value in 30 years, $\%$ of GDP); total coefficient of birth rate; age structure of population in 20 years, i.e., ratio of the quantity of population older than 65 years to the quantity of the full-aged;

$3^{\text {rd }}$ cluster - managing assets and liabilities: gross financing, i.e., sum of the value of budget balance and national debt to be paid (\% of GDP); share of short-term national debt in the total value of national debt; weighting average remaining maturity of national debt (years); ratio of short-term external national debt to the value of gold and foreign exchange reserves; share of external national debt in the total volume of national debt.

Indicators of the $1^{\text {st }}$ cluster how the influence of the policy conducted at the present time and planned for near future; indicators of the $2^{\text {nd }}$ cluster characterize economic and demographic policy in long-run period; indicators of the $3^{\text {rd }}$ cluster evaluate the structure of assets and liabilities. For each of these indicators, the threshold values are calculated with the least number of errors for the forecast of crisis and non-crisis situations. Then, for each indicator, the frequency of errors in the forecast of crisis and non-crisis situations at the level of its threshold value is calculated.

As a result of expert procedure, each indicator is assigned with weight and aggregated index of fiscal stress for the planned year is built.

3. Creating conditions for internal debt paying capacity of the state.

One of the main factors of sustainable long-term economic development of our country is stabilization of national debt and increase of paying capacity of Russia in the long term.

4. Developing the methodology of calculation of aggregated indicator of openness of the budget of the Russian 
Federation.

$1^{\text {st }}$ step. Calculation of the share of legally valid electronic documents in the total volume of documents of financial and economic activity of federal organizations of state administration sector.

$2^{\text {nd }}$ step. Calculation of indicator which characterizes the reduction of the time of processing of financial documentation of federal organizations of state administration sector.

$3^{\text {rd }}$ step. Calculation of the share of information, allocated on the unified web-site of the budget system of the Russian Federation in real time

$4^{\text {th }}$ step. Determination of the share of subjects (municipal entities) of the RF which have access to the "Electronic budget" system.

$5^{\text {th }}$ step. Determination of aggregated indicator of openness of the budget system of the Russian Federation.

\section{Conclusion}

The offered methodological approach will facilitate the detection of risk factors for sustainable development of budget system and determination of rational targeted indicators for long-term budget planning. New methods of evaluation of sustainability of budget system should be accompanied with new budget rules, which will facilitate the procyclical budget policy for oil and gas share of the budget and support macro-economic indicators at the safe level.

Usage of these approaches for preservation of sustainability of budget system should be the basis for short-term period when orienting at estimate indicators and budget rules in long-term aspect of development of the budget system of the Russian Federation.

Generalizing the above, it is possible to make the following conclusions regarding directions of improvement of institutions of budget sustainability.

The main institutions of provision of sustainability budget system are: strategic planning, program-targeted budget, electronic budget, financial rules, public-private partnership, and new pension formula. Evaluation of sustainability of budget system requires the use of step-by-step algorithm which includes the determination of the following:

1) aggregated indicator of sustainability of the federal budget on the basis of macro-economic indicators;

2) aggregated index of fiscal stress;

3) necessary conditions of internal debt paying capability of the state;

4) aggregated indicator of openness of Russia's budget.

Substantiated directions in determination of sustainability of the budget system will facilitate the strengthening of the balance of the budget system of the Russian Federation, gradual reduction of oil and gas deficit of the federal budget, preservation of the volume of Russia's national debt on the safe level, formation of budget parameters on the basis of current expenditure obligations, and regularity of analysis and diagnostics of risks for the budget system of the Russian Federation, which could be used for long-term budget planning.

\section{References}

Colander, D. (2004). From Muddling Through to the Economics of Control: Views of Applied Policy from J. N. Keynes to Abba Lerner. History of Political Economy, 37(5), 277-291.

Dryzek, J. (1996). The Informal Logic of Institutional design. In R. Goodin (Ed.), The Theory of Institutional Design (p. 105). http://dx.doi.org/10.1017/cbo9780511558320.005

Hughes, R., \& Joseffs, T. et al. (2014). The International Monetary Fund. Report "The Russian Federation: evaluation of transparency in fiscal sphere".

Kaul, I., \& Kunsisanu, P. (Eds.). (2006). New state finances. Response to global challenges. Published for the Program of Development of the UN. New York, Oxford - Oxford University Press Publ.

Kuzminov, Y. I. et al. (2005). Institutions: from borrowing to growth. Experience of Russian reforms and possibilities of cultivation of institutional changes. Modernization of economy and growth of institutions: VI International scientific conference (Moscow, April 5-7, 2005, p. 9). State University - Higher School of Economics Publ.

Leontyev, P. A. (2011). Institutional environment of formation of mechanism of development of the banking services sphere in the period of formation of post-service model of economic development. Issues of 
economics and law, 5, 41.

Morgner, M., Simanovic, G., \& Kirchner, R. (2015, March). Role of fiscal transparency in the increase of efficiency of government expenditures. Analytical notes. Berlin/Minsk.

Olson, M. (1998). The rise and decline of nations. Economic growth, stagflation, and social rigidities (p. 32). Novosibirsk.

Scott, W. (1995). Institution and organization (p. 34). Tionsand Oaks: Sage Publication.

Vlasov, S., Deryugina, E., \& Vlasova, Y. (2013). Study of sustainability of state finances of Russia in short-term and long-term periods. Issues of economics, 3.

\section{Copyrights}

Copyright for this article is retained by the author(s), with first publication rights granted to the journal.

This is an open-access article distributed under the terms and conditions of the Creative Commons Attribution license (http://creativecommons.org/licenses/by/3.0/). 